\title{
Molecular characterization of the virulent microorganisms along with their drug-resistance traits associated with the export quality frozen shrimps in Bangladesh
}

\author{
Rashed Noor ${ }^{1 *}$, Md Faqrul Hasan ${ }^{2}$ and M Majibur Rahman²
}

\begin{abstract}
Current investigation characterized export quality shrimp samples in terms of pathogenic load along with the drug-resistance traits of the isolates, and detected the major virulent genes present in those isolates. Among the 30 such shrimp samples (15 each of Macrobrachium rosenbergi or Golda and Penaeus monodon or Bagda) studied, almost all were found to be contaminated with a huge load of bacteria $\left(10^{6}-10^{8} \mathrm{cfu} / \mathrm{g}\right)$ and fungi $\left(10^{4}-10^{5} \mathrm{cfu} / \mathrm{g}\right)$. Among the specific pathogens, presence of Escherichia coli, Vibrio spp., Aeromonas spp., Klebsiella spp., Shigella spp., Staphylococcus spp. and Listeria spp. were detected, of which most were likely to be resistant against commonly used antibiotics. Gene specific polymerase chain reaction (PCR) study revealed the presence of eae gene in E. coli, aero specific gene in Aeromonas spp., and sodB gene in Vibrio spp. Together with the huge extent of microbial contamination with a drug-resistance attribute, presence of such virulent genes further projects the probable public health risk upon consumption of the export quality shrimps.
\end{abstract}

Keywords: Consumer health safety; Drug-resistance; Export quality frozen shrimps; Microorganisms; Virulence genes

\section{Background}

Export quality frozen shrimps encompass one of the foremost economic importance in Bangladesh (Rahman et al. 2012; Ahmed et al. 2013). However, being into the category of seafood, shrimps are likely to prone to microbial attack resulting in various food-borne diseases upon consumption (Karunasagar et al. 1994; Huss 1997; Wallace et al. 1999; Butt et al. 2004; Sawhney 2005; Rahman et al. 2012; Noor et al. 2013; Hassan et al. 2013; Ahmed et al. 2013). Microbiological proliferation not only in the shrimp but also in other sea foods is mainly dependent on the condition of transport, handling and processing (Rahman et al. 2012; Noor et al. 2013; Hassan et al. 2013; Ahmed et al. 2013; Sultana et al. 2014). Insufficiently iced and improper storage of shrimps at high temperature enhances the growth and access of microorganisms into the shrimps (Deepanjali et al. 2005;

\footnotetext{
* Correspondence: noor.rashed@yahoo.com

'Department of Microbiology, Stamford University Bangladesh, 51 Siddeswari Road, Dhaka 1217, Bangladesh

Full list of author information is available at the end of the article
}

Ghalis et al. 2010; Rahman et al. 2012; Hassan et al. 2013; Ahmed et al. 2013; Sultana et al. 2014). Furthermore, the existence of virulent genes could be of significance since these genes attribute to the pathogenesis of the contaminating bacteria, resulting in disease outbreaks (Cebula et al. 1995; Huq et al. 2005; Friesen et al. 2006; Yogananth et al. 2009; Hotopp 2011; Amin and Salem 2012; Yuan et al. 2013).

At present, nearly 40 shrimp species (principally Penaeus monodon and Macrobrachium rosenbergii) are cultivated in Bangladesh. However, the microbiological quality and the safety of these export quality shrimps still remain unidentified except a few reports (Rahman et al. 2012; Hassan et al. 2013; Ahmed et al. 2013; Sultana et al. 2014). Fish borne pathogenic dissemination principally relies on several factors including environment, demography, food habits and immune status of individuals (World Health Organization 2008; Rahman et al. 2012; Hassan et al. 2013; World Health Organization 2013; Sultana et al. 2014). Distribution and preparation prior to consumption of such fish may also lead to the onset of 
several disease outbreaks (World Health Organization 2008; Rahman et al. 2012). Therefore, the aptitude of progression as well as the continued existence of bacteria must be measured not only to detect the microbiological quality but also to assess the consumer safety of such stored fish products.

In this perspective, we attempted to monitor the microbial pathogenic load randomly in export quality shrimps. Our study was designed to 1 ) identify and enumerate the pathogens associated with the shrimps dedicated for export; 2) to detect the drug-resistance traits of the isolates, and 3) finally to detect the presence of virulent genes in the pathogenic isolates.

\section{Results}

Prevalence of microorganisms within the export quality shrimp samples

All the 30 samples studied in the current investigation regardless of the species were found to hugely populated with the total viable bacteria (TVB) within a range of $10^{6}-$ $10^{8} \mathrm{cfu} / \mathrm{g}$, and with a fungal load of around $10^{4}-10^{5} \mathrm{cfu} / \mathrm{g}$ (Table 1). The total viable bacterial load was noticed to be 1 or 2-log higher in the head fractions compared to those in the body and tail portions. Among the pathogenic bacteria, Staphylococcus spp. were quantified within all samples tested with a bio-burden of $10^{4}-10^{6} \mathrm{cfu} / \mathrm{g}$. While fecal coliforms were absent in all samples, E. coli, Klebsiella spp. and Shigella spp. were found to be present in a very few samples (Tables 1 and 2). Growth and proliferation of Vibrio spp. and Aeromonas spp. was also observed to similar extent as noticed in case the enteric bacteria. Surprisingly, most of the samples were found to be contaminated with Listeria spp. $\left(10^{4}-10^{6} \mathrm{cfu} / \mathrm{g}\right)$. Overall, the proliferation of staphylococcal species and Listeria spp. was found to be predominant compared to the enteric pathogenic bacteria; while Salmonella spp., Pseudomonas spp. and Clostridium spp. were found to be completely absent in samples tested.

\section{Drug-resistance trait of the pathogenic isolates}

All types of the pathogenic isolates found in the export quality shrimp samples showed resistance against the commonly used antibiotics (Table 3). The tested isolates of E. coli and Staphylococcus were found to be resistant against erythromycin. Ampicillin resistance was also found in E. coli isolates; while the selected isolates of both Listeria spp. and Staphylococcus spp. were found to exhibit the resistance traits against trimethoprime/

Table 1 Microbial load (cfu/g) in the export quality shrimp samples

\begin{tabular}{|c|c|c|c|c|c|c|c|c|c|c|}
\hline "Sample no. & Sample fractions & TVB & Total fungi & E. coli & $\begin{array}{l}\text { Vibrio } \\
\text { spp. }\end{array}$ & $\begin{array}{l}\text { Klebsiella } \\
\text { spp. }\end{array}$ & $\begin{array}{l}\text { Aeromonas } \\
\text { spp. }\end{array}$ & $\begin{array}{l}\text { Shigella } \\
\text { spp. }\end{array}$ & $\begin{array}{l}\text { Staphylococcus } \\
\text { spp. }\end{array}$ & $\begin{array}{l}\text { Listeria } \\
\text { spp. }\end{array}$ \\
\hline \multirow[t]{3}{*}{ Samples 1-3 } & Head & $1.5 \times 10^{8}$ & $1.8 \times 10^{5}$ & $1 \times 10^{3}$ & $2.8 \times 10^{2}$ & $1.3 \times 10^{2}$ & $1.4 \times 10^{2}$ & $2.6 \times 10^{2}$ & $9.1 \times 10^{6}$ & $1 \times 10^{5}$ \\
\hline & Body & $1.5 \times 10^{7}$ & $5.4 \times 10^{4}$ & 0 & 0 & 0 & $1.3 \times 10^{2}$ & 0 & $4.1 \times 10^{5}$ & 0 \\
\hline & Tail & $7.6 \times 10^{6}$ & $4.1 \times 10^{5}$ & 0 & 0 & 0 & 0 & 0 & $2 \times 10^{6}$ & $5.3 \times 10^{4}$ \\
\hline \multirow[t]{3}{*}{ Samples 4-9 } & Head & $2.1 \times 10^{7}$ & $1.1 \times 10^{4}$ & 0 & 0 & 0 & $4.7 \times 10^{2}$ & 0 & $1.5 \times 10^{4}$ & $1 \times 10^{2}$ \\
\hline & Body & $1.3 \times 10^{6}$ & $1.2 \times 10^{4}$ & 0 & 0 & 0 & 0 & 0 & $2.3 \times 10^{3}$ & $1.1 \times 10^{3}$ \\
\hline & Tail & $2.8 \times 10^{6}$ & $1.5 \times 10^{4}$ & 0 & 0 & 0 & 0 & 0 & $2 \times 10^{2}$ & $2.1 \times 10^{3}$ \\
\hline \multirow[t]{3}{*}{ Samples 10-15 } & Head & $1.2 \times 10^{8}$ & $1.8 \times 10^{5}$ & $1.2 \times 10^{2}$ & $1.3 \times 10^{2}$ & $1.1 \times 10^{2}$ & $3.2 \times 10^{2}$ & $2.6 \times 10^{2}$ & $3.4 \times 10^{4}$ & $1 \times 10^{3}$ \\
\hline & Body & $1.1 \times 10^{7}$ & $5.4 \times 10^{4}$ & $1 \times 10^{2}$ & 0 & 0 & $1.2 \times 10^{2}$ & 0 & $2.2 \times 10^{3}$ & 0 \\
\hline & Tail & $1.3 \times 10^{6}$ & $4.1 \times 10^{5}$ & 0 & 0 & 0 & 0 & 0 & $2.3 \times 10^{4}$ & $1.3 \times 10^{3}$ \\
\hline \multirow[t]{3}{*}{ Samples 16-21 } & Head & $3.4 \times 10^{7}$ & $1.8 \times 10^{5}$ & 0 & 0 & 0 & 0 & 0 & $2.6 \times 10^{5}$ & $1 \times 10^{2}$ \\
\hline & Body & $2.5 \times 10^{6}$ & $5.4 \times 10^{4}$ & 0 & 0 & 0 & 0 & 0 & $3.3 \times 10^{5}$ & $1.3 \times 10^{2}$ \\
\hline & Tail & $1.4 \times 10^{6}$ & $4.1 \times 10^{5}$ & 0 & 0 & 0 & 0 & 0 & $1.2 \times 10^{5}$ & $4.3 \times 10^{2}$ \\
\hline \multirow[t]{3}{*}{ Samples 22-27 } & Head & $2.5 \times 10^{8}$ & $1.8 \times 10^{5}$ & $1 \times 10^{2}$ & $1.5 \times 10^{2}$ & $1.1 \times 10^{2}$ & $1.9 \times 10^{2}$ & $1.2 \times 10^{2}$ & $1.1 \times 10^{6}$ & $1.3 \times 10^{2}$ \\
\hline & Body & $1.9 \times 10^{6}$ & $5.4 \times 10^{4}$ & 0 & 0 & 0 & 0 & 0 & $1.2 \times 10^{4}$ & 0 \\
\hline & Tail & $1.2 \times 10^{6}$ & $4.1 \times 10^{5}$ & 0 & 0 & 0 & 0 & 0 & $2.8 \times 10^{5}$ & $2.4 \times 10^{2}$ \\
\hline \multirow[t]{3}{*}{ Samples 28-30 } & Head & $1.7 \times 10^{7}$ & $1.8 \times 10^{5}$ & 0 & 0 & 0 & $1.8 \times 10^{2}$ & 0 & $5.3 \times 10^{5}$ & $1 \times 10^{4}$ \\
\hline & Body & $1.2 \times 10^{6}$ & $5.4 \times 10^{4}$ & 0 & 0 & 0 & 0 & 0 & $2.4 \times 10^{4}$ & $1.2 \times 10^{2}$ \\
\hline & Tail & $1.6 \times 10^{6}$ & $4.1 \times 10^{5}$ & 0 & 0 & 0 & 0 & 0 & $2.4 \times 10^{4}$ & $2.4 \times 10^{2}$ \\
\hline
\end{tabular}

*Samples 1-3 (Macrobrachium rosenbergi) = collected within July 2011-September 2011, Samples 4-9 (Macrobrachium rosenbergi) = collected within October 2011-March 2012, Samples 10-15 (Penaeus monodon) = collected within April 2012-September 2012, Samples 16-21 (Penaeus monodon)= collected within October 2012-March 2013, Samples 22-27 (Macrobrachium rosenbergi): Collected within: April 2013 -September 2013, Samples 28-30 (Penaeus monodon) = collected within October 2013December 2013.

TVB: Total viable bacteria.

Average bacterial load (cfu/g) in each category has been shown and fecal coliforms, Salmonella spp., Pseudomona spp. and Clostridium spp. were absent. 
Table 2 Results of biochemical tests of the pathogenic isolates

\begin{tabular}{|c|c|c|c|c|c|c|c|c|c|c|c|}
\hline \multirow[t]{2}{*}{ Assumed pathogenic isolates } & \multicolumn{4}{|c|}{ TSI } & \multirow[t]{2}{*}{ Motility } & \multirow[t]{2}{*}{ Indole production } & \multirow[t]{2}{*}{ MR } & \multirow[t]{2}{*}{ VP } & \multirow[t]{2}{*}{ Citrate utilization } & \multirow[t]{2}{*}{ Catalase } & \multirow[t]{2}{*}{ Oxidase } \\
\hline & Slant & Butt & Gas & $\mathrm{H}_{2} \mathrm{~S}$ & & & & & & & \\
\hline Staphylococcus aureus & Y & Y & - & - & - & - & + & + & - & + & - \\
\hline Escherichia coli & Y & Y & + & - & + & + & + & - & - & + & - \\
\hline Klebsiella spp. & Y & Y & + & - & + & - & - & + & + & + & - \\
\hline Shigella spp. & R & Y & - & - & - & + & + & - & - & + & + \\
\hline Vibrio spp. & $\mathrm{R}$ & Y & - & - & + & - & + & - & - & + & + \\
\hline Aeromonas spp. & $\mathrm{R}$ & Y & + & - & + & - & - & + & + & + & + \\
\hline
\end{tabular}

TSI = Triple Sugar Iron Test, $\mathrm{Y}=$ Yellow (Acidic), + = presence, $-=$ absence, $\mathrm{R}=$ Red (Alkaline), MR = Methyl Red, VP= Voges-Proskauer.

sulfamethoxazole and Polymixin B (Table 3). In addition, the tested isolates of Listeria spp. were found to be resistant against penicillin $\mathrm{G}$ (Table 3).

\section{Presence of virulent genes in the pathogenic isolates}

The gene specific PCR study revealed the presence of eae gene in the tested $E$. coli isolates (as shown for 2 samples in Figure 1A). The screened isolates of Aeromonas spp. exhibited the presence of aero specific gene (Figure 1B); while the $\operatorname{sod} B$ gene known to be encoding SodB virulence protein in Vibrio spp. was found to be present in one sample (Figure 1C). The tested isolates of S. flexineri were found to be devoid of $s t x 1$ virulence gene (Figure 1D).

\section{Discussion}

Fisheries sector in Bangladesh has been considered to hold the second highest position for earning foreign currencies (Rahman et al. 2012). Unfortunately since many fish processing plants in Bangladesh are devoid of following the HACCP guidelines as well as the hygienic regulations, the imported products could pose risk towards the consumer safety (Antony et al. 2002). Along with this public health risk point, in order to set remedies, regular microbiological quality demonstration of the finished products is thus of essence. Our earlier work demonstrated a huge microbial contamination level not only in the frozen shrimp samples, but also in other sea fish products available in markets (Rahman et al. 2012;

Table 3 Antibiogram of the pathogenic isolates

\begin{tabular}{|c|c|c|c|c|c|c|c|c|c|c|c|c|}
\hline \multirow{2}{*}{$\begin{array}{l}\text { Organisms } \\
\text { Antibiotics }\end{array}$} & \multicolumn{2}{|c|}{$\begin{array}{c}\text { E. coli } \\
\mathrm{n}=6\end{array}$} & \multicolumn{2}{|c|}{$\begin{array}{c}\text { Klebsiella spp. } \\
\mathrm{n}=4\end{array}$} & \multicolumn{2}{|c|}{$\begin{array}{l}\text { Shigella spp. } \\
n=3\end{array}$} & \multicolumn{2}{|c|}{$\begin{array}{c}\text { Vibrio spp. } \\
n=7\end{array}$} & \multicolumn{2}{|c|}{$\begin{array}{l}\text { Listeria spp. } \\
\mathrm{n}=4\end{array}$} & \multicolumn{2}{|c|}{$\begin{array}{c}\text { Staphylococcus } \\
\text { spp. } n=5\end{array}$} \\
\hline & $\mathbf{R}$ & $\mathrm{S}$ & $\mathbf{R}$ & $\mathrm{S}$ & $\mathbf{R}$ & $\mathrm{S}$ & $\mathbf{R}$ & $\mathrm{S}$ & $\mathbf{R}$ & $\mathrm{S}$ & $\mathbf{R}$ & $\mathrm{S}$ \\
\hline Ampicillin $(10 \mu \mathrm{g})$ & $20 \%$ & $80 \%$ & $80 \%$ & $20 \%$ & $79 \%$ & $21 \%$ & $80 \%$ & $20 \%$ & $100 \%$ & $0 \%$ & $99 \%$ & $1 \%$ \\
\hline Ciprofloxacin $(5 \mu \mathrm{g})$ & $67 \%$ & $33 \%$ & $98 \%$ & $2 \%$ & $10 \%$ & $90 \%$ & $10 \%$ & $90 \%$ & $60 \%$ & $40 \%$ & ND & ND \\
\hline Polymixin B (300 unit) & $33 \%$ & $67 \%$ & $96 \%$ & $4 \%$ & ND & ND & ND & ND & $100 \%$ & $0 \%$ & $90 \%$ & $10 \%$ \\
\hline Cefixime $(30 \mu \mathrm{g})$ & $67 \%$ & $33 \%$ & $100 \%$ & $0 \%$ & $2 \%$ & $98 \%$ & $70 \%$ & $30 \%$ & ND & ND & ND & ND \\
\hline Amoxicillin $(10 \mu \mathrm{g})$ & $33 \%$ & $67 \%$ & $87 \%$ & $12 \%$ & $17 \%$ & $83 \%$ & ND & ND & $90 \%$ & $10 \%$ & $100 \%$ & $1 \%$ \\
\hline Ceftriazone $(5 \mu \mathrm{g})$ & $0 \%$ & $100 \%$ & $0 \%$ & $100 \%$ & $9 \%$ & $91 \%$ & $70 \%$ & $30 \%$ & ND & ND & ND & ND \\
\hline Penicillin $(10 \mu \mathrm{g})$ & ND & ND & ND & ND & ND & ND & ND & ND & $100 \%$ & $0 \%$ & $99 \%$ & $1 \%$ \\
\hline Chloramphenicol (10 $\mu \mathrm{g})$ & $45 \%$ & $55 \%$ & $24 \%$ & $76 \%$ & $52 \%$ & $48 \%$ & $40 \%$ & $60 \%$ & $35 \%$ & $65 \%$ & ND & ND \\
\hline 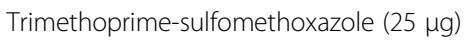 & $20 \%$ & $80 \%$ & $18 \%$ & $82 \%$ & $1 \%$ & $99 \%$ & $60 \%$ & $40 \%$ & $70 \%$ & $30 \%$ & $30 \%$ & $70 \%$ \\
\hline Gentamycin $(10 \mu \mathrm{g})$ & ND & ND & ND & ND & $0 \%$ & $100 \%$ & ND & ND & $15 \%$ & $85 \%$ & $34 \%$ & $66 \%$ \\
\hline Kanamycin $(30 \mu \mathrm{g})$ & ND & ND & ND & ND & ND & ND & ND & ND & $80 \%$ & $20 \%$ & ND & ND \\
\hline Nalidixic acid (30 $\mu \mathrm{g})$ & $80 \%$ & $20 \%$ & $75 \%$ & $25 \%$ & $99 \%$ & $1 \%$ & $60 \%$ & $40 \%$ & ND & ND & ND & ND \\
\hline Vancomycine $(30 \mu \mathrm{g})$ & ND & ND & ND & ND & $100 \%$ & $0 \%$ & ND & ND & $10 \%$ & $90 \%$ & $70 \%$ & $30 \%$ \\
\hline Erythromycin $(15 \mu \mathrm{g})$ & ND & ND & ND & ND & ND & ND & $10 \%$ & $80 \%$ & $20 \%$ & $80 \%$ & $25 \%$ & $75 \%$ \\
\hline Tetracycline (305 $\mu \mathrm{g})$ & $10 \%$ & $90 \%$ & $20 \%$ & $80 \%$ & ND & ND & ND & ND & $10 \%$ & $90 \%$ & $0 \%$ & $100 \%$ \\
\hline Streptomycin $(10 \mu \mathrm{g})$ & $45 \%$ & $55 \%$ & $85 \%$ & $15 \%$ & ND & ND & $25 \%$ & $75 \%$ & ND & $N D$ & $10 \%$ & $90 \%$ \\
\hline
\end{tabular}

$\mathrm{n}=$ Number of isolates, ND = Not done, $\mathrm{R}=$ Resistant, $\mathrm{S}=$ Sensitive.

All the experiments have been done three times and the results were reproducible. One representative data have been shown. 


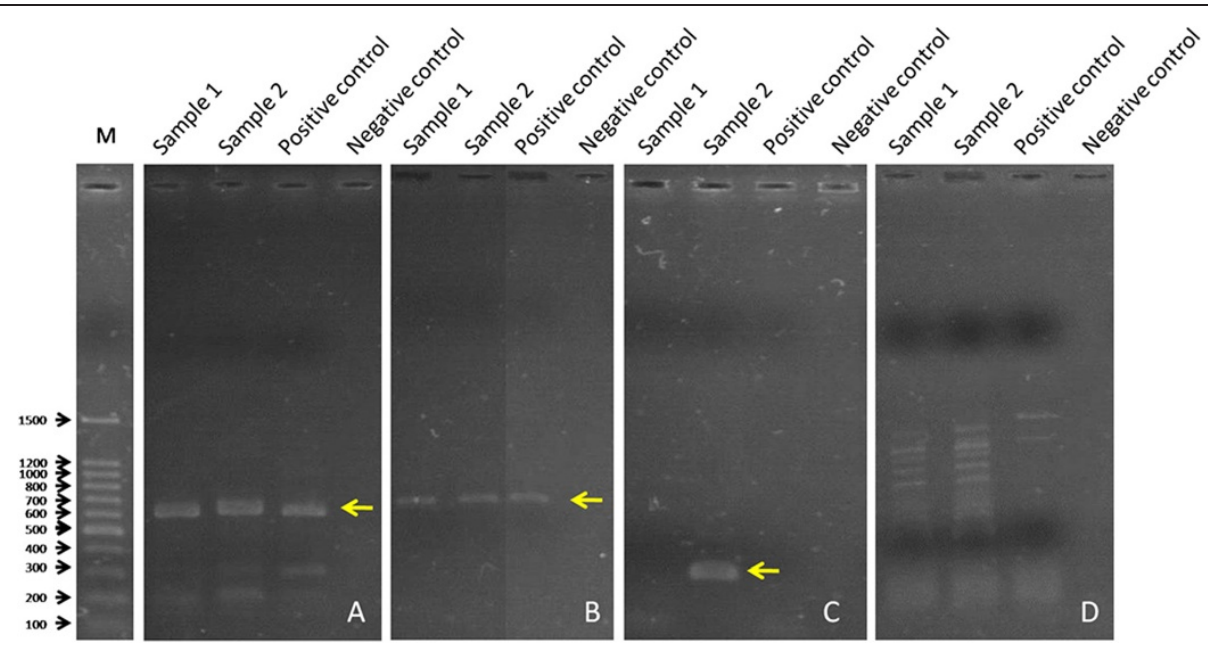

Figure 1 PCR analysis of pathogenic isolates. The presence of the specific virulence genes: eae gene (A), Aeromonas spp. specific gene (B), Vibrio cholerae specific sodB gene (C), and STEC specific stx 1 gene (D). For positive controls, template DNA from EPEC ATCC 13706 (A), Aeromonas ATCC 7966 (B), Vibrio cholerae O1 ATCC 1966 (C), and Shigella flexineri strains (D) were used. M: Marker.

Hassan et al. 2013; Ahmed et al. 2013; Sultana et al. 2014). In cohort with those findings, in our current study, similar scenario of microbiological prevalence within the shrimp samples was noticed, possibly due to the lack of hygienic maintenance during the finished product processing and inappropriate storage.

An array of preservatives and drugs including sulphonamides, tetracycline, amoxicillin, trimethoprim-sulphamethoxine and quinolones are being used worldwide in aquaculture to prevent infection of aquatic lives (Rajadurai 1985; Angulo 1999). However, the emergence of drugresistant bacteria is a burning health issue in terms of disease eradication (Alam et al. 2014). Interestingly in the current investigation, the tested bacterial isolates were found almost to be resistant against the antibiotics employed. Such a demonstration of the drug-resistant bacterial contamination within the export quality shrimps not only provokes the risk of overall consumer safety but also renders the medication inefficiency during the food borne disease outbreaks. So far our knowledge, investigation of the drug-resistance traits of contaminant bacteria within the export quality shrimps from Bangladesh has been conducted for the first time, and nevertheless, the appropriate measures against the spread of microorganisms within the packed export items would prevent the possible onset of disease among the global consumers.

Finally our investigation on the propagation of the virulent genes within the export quality shrimps demonstrated the molecular basis of shrimp related fatality upon consumption. Previously we only detected the pathogenic microbial prevalence within the shrimp samples; however, the presence of virulence genes was not clarified (Rahman et al. 2012). The detection of the virulent genes in the supplied shrimp samples indeed is thought to aid in the effective treatment during food borne disease outbreaks (Ahmed et al. 2013; Rahman et al. 2012). In the present study, the presence of eae, $\operatorname{sodB}$ and aero specific genes within the export quality shrimp samples are indicative of the pathogenesis potential of the contaminant bacteria isolated in the samples (Zhang et al. 2000; Postollec, et al. 2011; Nakamura et al. 2013).

\section{Conclusions}

Overall, according to our study, export quality shrimps have been found to harbor many pathogens including the vital virulent genes indicating that these are not protected from contamination during subsequent handling, packaging, storage, and transport. The presence of drugresistance isolates is suggestive of medication complications if the onset of food borne disease is in its epidemic form. In these perspectives, the microbiological quality analysis is a vital aspect of the export quality shrimp quality.

\section{Methods}

Sampling, sample processing and microbiological analysis A total of 30 export quality frozen shrimp samples, among which 15 were Macrobrachium rosenbergi (locally named as Golda) and another 15 were Penaeus monodon (locally named as Bagda), were collected in a haphazard manner from a shrimp processing industry of Cox's Bazar within a time frame of July 2011-December 2013. Samples were transported immediately to the Microbiology Laboratory in icebox maintaining the temperature of $4^{\circ} \mathrm{C}$ (American Public Health Association 1970; American Public Health Association 1998; Rahman et al. 2012). Each sample was processed through blending of $10 \mathrm{~g}$ sample (head, body, 
tail separately) in $90 \mathrm{ml}$ peptone water following the preparation of serial dilutions up to $10^{-6}$ for microbiological analysis. Different types of differential and selective culture media were used to isolate and enumerate an array of bacteria and fungi. Morphological characteristics including color, shape, elevation, surface texture, opacity, etc. of the colonies on different media were recorded. The size and shape of the cells were observed by Gram staining (Cappuccino and Sherman 1996). For the quantification of total viable bacteria (TVB) and fungi, $0.1 \mathrm{ml}$ of each sample was introduced onto the nutrient agar (NA) and Sabouraud's dextrose agar (SDA) plates, respectively, by means of spread plate technique (Cappuccino and Sherman 1996). Plates were incubated at $37^{\circ} \mathrm{C}$ for 24 hours and at $25^{\circ} \mathrm{C}$ for 48 hours for total viable bacteria and fungi, respectively.

\section{Isolation of pathogenic bacteria}

To isolate Escherichia coli and Klebsiella spp. from each $10^{-1}$ to $10^{-3}$ dilution tubes, $0.1 \mathrm{ml}$ suspension was spread over the surface of MacConkey agar medium. Following incubation at $37^{\circ} \mathrm{C}$ for 18 to 24 hours, the plate was observed for the growth of characteristic colonies. The presence of $E$. coli was further confirmed by the appearance of bluish-black colonies with green metallic sheen on Eosin-Methylene Blue (EMB) agar medium (Cappuccino and Sherman 1996).

One $\mathrm{ml}$ of homogenized sample was transferred to $9 \mathrm{ml}$ of selenite cystine broth and alkaline peptone water $\left(10^{-1}\right.$ dilution) for enrichment of Salmonella spp., Shigella spp. and Vibrio spp., respectively, which were then incubated at $37^{\circ} \mathrm{C}$ for 6 hours (Rahman and Noor 2012). Then $1 \mathrm{ml}$ of enriched broth was subjected to 10 -fold serial dilution up to $10^{-2}$ to $10^{-6}$ in $9 \mathrm{ml}$ of normal saline. From each $10^{-4}$ to $10^{-6}$ dilution tubes, $0.1 \mathrm{ml}$ of suspension was spread onto XLD and TCBS agar plates. After incubating at $37^{\circ} \mathrm{C}$ for $24 \mathrm{hrs}$, characteristic colonies were detected and enumerated.

To isolate Listeria monocytogenes from $10^{-3}, 10^{-5}, 10^{-6}$ dilution tubes, $0.1 \mathrm{ml}$ suspension was spread onto Listeria isolation media and was incubated at $37^{\circ} \mathrm{C}$ for
$24 \mathrm{hr}$. Colonies appeared as olive green were detected and counted as Listeria monocytogenes. For the isolation of Clostridium perfringens, each sample was mixed in sterile saline in a ratio of $1: 8$ and was heated at $80^{\circ} \mathrm{C}$ for 15 minutes in order to kill vegetative cells. Then $1 \mathrm{ml}$ heated suspension was allowed to grow at $37^{\circ} \mathrm{C}$ in $9 \mathrm{ml}$ fluid thioglycolate broth for $4 \mathrm{hrs}$. Afterward, $1 \mathrm{ml}$ of enriched broth was subjected to 10 -fold serial dilution from $10^{-1}$ to $10^{-6}$ in $9 \mathrm{ml}$ of normal saline. From each $10^{-4}$ to $10^{-6}$ dilution tubes, $0.1 \mathrm{ml}$ of suspension was pour plated on Perfringens agar medium. The plates were then incubated at $37^{\circ} \mathrm{C}$ in a candle jar for $48 \mathrm{hrs}$. Colonies appeared as black were detected and counted as Clostridium perfringens. A series of biochemical tests were performed to identify the bacteria of interest following standard protocol (Cappuccino and Sherman 1996; Rahman et al. 2012). Briefly, the triple sugar iron test (TSI), Methyl Red (MR) test, Voges-Proskauer (VP), oxidase test and catalase tests were conducted to identify the bacterial isolates (Table 2). This is to be mentioned that around $10-20 \%$ of the identical colonies on the bacterial selective media were subjected to the confirmative biochemical identification.

\section{Determination of antimicrobial susceptibility of the isolates} Isolates were tested for antibiotic susceptibility on MuellerHinton ( $\mathrm{MH}$ ) agar (Difco, Detroit, $\mathrm{MI}$ ) against trimethoprime/sulfamethoxazole $(25 \mu \mathrm{g})$, erythromycin $(15 \mu \mathrm{g})$, amoxicillin $(30 \mu \mathrm{g})$, ceftriaxone $(30 \mu \mathrm{g})$, ciprofloxacin $(5 \mu \mathrm{g})$, streptomycin $(10 \mu \mathrm{g})$, ampicillin $(10 \mu \mathrm{g})$, tetracycline $(30 \mu \mathrm{g})$, chloramphenicol $(30 \mu \mathrm{g})$, cefixime $(5 \mu \mathrm{g})$, polymixin B (300 units), kanamycin $(30 \mu \mathrm{g})$, vancomycin $(30 \mu \mathrm{g})$, gentamicin $(10 \mu \mathrm{g})$, nalidixic acid $(30 \mu \mathrm{g})$, azythromycin $(15 \mu \mathrm{g})$ and penicillin $\mathrm{G}(10 \mu \mathrm{g})$ by modified KirbyBauer method (Bauer et al. 1966; Munshi et al. 2012). Cell suspensions of the bacterial isolates were prepared by inoculating a single colony into $2 \mathrm{ml}$ of $\mathrm{MH}$ broth, and after a brief incubation for 4 hours (when the culture turbidity was equivalent to $0.5 \mathrm{McF}$ arland standard), bacterial lawns were prepared over the $\mathrm{MH}$ agar, and the antibiotic discs were placed aseptically over the surface. After

Table 4 List of primers used in this study

\begin{tabular}{|c|c|c|c|c|}
\hline Primer names & Sequence of primers & Target gene & Size (bp) & Strains \\
\hline eae $F$ & 5'-CTGAACGGCGATTACGCGAA-3' & eae & 917 & EPEC \\
\hline eae $R$ & 3'-CCAGACGATACGATCCAG-5' & & & \\
\hline stx1 $F$ & 5'-ATAAATCGCCATTCGTTGACTAC-3' & stx 1 & 180 & STEC \\
\hline stx1 R & 3'-AGAACGCCCACTGAGATCATC-5' & & & \\
\hline aero $\mathrm{F}$ & 5'-TAGCTTGCTACTIITGCCGG-3' & aero spcific & & Aeromonas spp \\
\hline aero $\mathrm{R}$ & 3'-GACACAGGAACTCTGCACCG-5' & & & \\
\hline sodB F & 5'-AAGACCTCAACTGGCGGTA-3' & $\operatorname{sod} B$ & 248 & V. cholerae \\
\hline $\operatorname{sodB} R$ & 3'-GAAGTGTTAGTGATCGCCAGAGT-5' & & & \\
\hline
\end{tabular}


12-18 hours of incubation, plates were examined and the diameters of the zones of inhibition were measured (in $\mathrm{mm}$ ) and interpreted as susceptible, intermediate and resistant (Ferraro et al. 2001).

\section{Detection of virulent genes through gene specific polymerase chain reaction (PCR)}

Genomic DNA from each of the bacterial isolates was extracted through the modified boiling method. Two or more colonies of each isolate were suspended into $500 \mu \mathrm{l}$ nuclease free reagent grade water in Eppendorf tubes, kept in a boiling water bath for 10 minutes, and immediately transferred to ice and kept for 10 minutes. After centrifugation at $10000 \mathrm{rpm}$ for 10 minutes, supernatants were collected and used as templates for specific gene amplification using respective primers through PCR (Table 4). The reaction mixture used for PCR consisted of $2.5 \mu \mathrm{l}$ of $10 \times$ buffer, $0.75 \mu \mathrm{l}$ of $\mathrm{MgCl}_{2}, 10 \mathrm{mM}$ dNTP mixture $(0.5 \mu \mathrm{l}), 1 \mu \mathrm{l}$ of each of the forward- and reverse primers $(10 \mathrm{mM}), 0.2 \mu \mathrm{l}$ of Taq polymerase $(5 \mathrm{U} / \mu \mathrm{l}), 1 \mu \mathrm{l}$ of the template DNA, and finally the volume of the mixture was made up to $25 \mu \mathrm{l}$ using $18.05 \mu \mathrm{l}$ sterile deionized water. A master mix was prepared for all the isolates simultaneously using the amounts mentioned above. After mixing the reaction mixture with the template DNA, the components were overlaid with a drop of mineral oil (Sigma Labs, Inc., USA). Finally the PCR tubes were centrifuged briefly to spin down the contents.

PCR amplification of the target DNA was carried out in a thermal cycler (Bio-Rad Laboratories, In., USA) as described earlier (Cebula et al. 1995; Yogananth et al. 2009; Amin and Salem 2012). Briefly, the amplification of eae gene consisted of initial denaturation at $95^{\circ} \mathrm{C}$ for 5 minutes followed by 35 cycles of denaturation at $92^{\circ} \mathrm{C}$ for 1 minute, primer annealing at $63^{\circ} \mathrm{C}$ for 2 minutes and extension at $72^{\circ} \mathrm{C}$ for 2 minutes and a final extension at $72^{\circ} \mathrm{C}$ for 7 minutes followed. Amplification of stx 1 was done with an initial denaturation at $95^{\circ} \mathrm{C}$ for 5 min followed by 35 cycles of denaturation at $95^{\circ} \mathrm{C}$ for 45 seconds, primer annealing at $61^{\circ} \mathrm{C}$ for 2 min and extension at $72^{\circ} \mathrm{C}$ for $1 \mathrm{~min}$ followed by the final extension at $72^{\circ} \mathrm{C}$ for 7 minutes. Amplification of aero- specific gene consisted of initial denaturation at $95^{\circ} \mathrm{C}$ for $5 \mathrm{mi}-$ nutes followed by 35 cycles of denaturation at $94^{\circ} \mathrm{C}$ for 40 seconds, primer annealing at $57^{\circ} \mathrm{C}$ for 1 minute, extension at $72^{\circ} \mathrm{C}$ for 2 minutes and a final extension at $72^{\circ} \mathrm{C}$ for 7 minutes. Amplification of $\operatorname{sod} B$ was performed with and initial denaturation at $95^{\circ} \mathrm{C}$ for 5 min followed by 35 cycles of denaturation at $94^{\circ} \mathrm{C}$ for 45 seconds, primer annealing at $58^{\circ} \mathrm{C}$ for $1 \mathrm{~min}$, extension at $72^{\circ} \mathrm{C}$ for $1 \mathrm{~min}$ followed by the final extension at $72^{\circ} \mathrm{C}$ for 7 minutes. PCR products were visualized following electrophoresis through $1.2 \%$ agarose gels stained with ethidium bromide, and the amplicons were identified based only on the size of the amplified product visualized by UV trans-illuminator (Gel Doc, Bio-Rad Laboratories, In., USA).

\section{Competing interests}

The authors declare that they have no competing interests.

\section{Authors' contributions}

This work was carried out in collaboration between all authors. Author RN designed the study, wrote the first draft of the manuscript and critically revised the manuscript. Authors MFH performed the experiments. Author MMR managed the literature searches. All authors read and approved the final manuscript.

\section{Acknowledgements}

Authors are thankful to Md. Sakil Munna, Kamal Kanta Das, Mrityunjoy Acharjee, Saurab Kishore Munshi and Farjana Rahman for their thoughtful advices and technical assistance during the experiments. The work was financed by the Ministry of Education, People's Republic of Bangladesh.

\section{Author details}

'Department of Microbiology, Stamford University Bangladesh, 51 Siddeswari Road, Dhaka 1217, Bangladesh. ${ }^{2}$ Department of Microbiology, University of Dhaka, Fullar Road, Dhaka 1000, Bangladesh.

Received: 15 June 2014 Accepted: 15 August 2014 Published: 26 August 2014

\section{References}

Ahmed T, Baidya S, Sharma BC, Malek M, Das KK, Acharjee M, Munshi SK, Noor R (2013) Identification of drug-resistant bacteria among export quality shrimp samples in Bangladesh. Asian J Microbiol Biotechnol Env Sci 15:31-36

Alam SMS, Kalam MA, Munna MS, Munshi SK, Noor R (2014) Isolation of pathogenic microorganisms from burn patients admitted in Dhaka Medical College and Hospital and demonstration of their drug-resistance traits. Asian Pac J Trop Dis 4:402-407

American Public Health Association (1970) Recommended procedures for the examination of seawater and shellfish. American Public Health Association, Washington, DC

American Public Health Association (1998) Standard methods for the examination of water and wastewater. American Public Health Association, Washington, DC

Amin RA, Salem AM (2012) Specific detection of pathogenic Vibrio species in shellfish by using multiplex polymerase chain reaction. Global Veterinaria 8:525-531

Angulo F, Antibiotic Use in Aquaculture: Centre for Disease Control Memo to the Record (1999) Use of antimicrobial agents in aquaculture: potential for public health impact. Public Health Service, Department of Health \& Human Services, Centres for Disease Control and Prevention (CDC)., p 5

Antony MM, Jeyasekaran G, Shakila RJ, Shanmugam SA (2002) Microbiological quality of raw shrimps processed in seafood processing plants of Tuticorin, Tamil Nadu, India. Asian Fish Sci 15:33-41

Bauer AW, Kirby WMM, Sherris JC, Turck M (1966) Antibiotic susceptibility testing by a standardized single disk method. Am J Clin Pathol 36:493-496

Butt AA, Aldridge KE, Sanders CV (2004) Infections related to the ingestion of seafood Part I: viral and bacterial infections. Lancet Infect Dis 4:201-212

Cappuccino JG, Sherman N (1996) Microbiology-a laboratory manuals. Benjamin/ Cummings Publishing Company Incorporated

Cebula TA, Payne WL, Feng P (1995) Simultaneous identification of strains of Escherichia coli serotype 0157:H7 and their Shiga-like toxin type by mismatch amplification mutation assay-multiplex PCR. J Clin Microbiol 33:248-250

Deepanjali A, Sanath KH, Karunasagar I (2005) Seasonal variation in abundance of total and pathogenic $V$. parahaemolyticus in oysters along the southwest coast of India. Appl Environ Microbiol 71:3575-3580

Ferraro MJ, Craig WA, Dudley MN (2001) Performance standards for antimicrobial susceptibility testing. National Committee for Clinical Laboratory Standards, Pennsylvania, USA

Friesen TL, Stukenbrock EH, Liu Z, Meinhardt S, Ling H, Faris JD, Rasmussen JB, Solomon PS, Mcdonald BA, Oliver RP (2006) Emergence of a new disease as a result of interspecific virulence gene transfer. Nat Genet 38:953-956 

preservation techniques: review. Am J Appl Sci 7:859-877

Hassan MR, Acharjee M, Das E, Das KK, Ahmed T, Akond MA, Fatema KK, Noor R (2013) Microbiological study of sea fish samples collected from local markets in Dhaka city. Int Food Res J 20:1491-1495

Hotopp JCD (2011) Horizontal gene transfer between bacteria and animals. Trends Genet 27:157-163

Huq A, Sack RB, Nizam A, Longini IM, Nair GB, Ali A (2005) Critical factors influencing the occurrence of Vibrio cholerae in the environment of Bangladesh. Appl Env Microbiol 71:464-4654

Huss HH (1997) Control of indigenous pathogenic bacteria in seafood. Food Control 8:91-98

Karunasagar I, Pai R, Malathi GR, Karunasagar I (1994) Mass mortality of Penaeus monodon larvae due to antibiotic resistant Vibrio harveyi infection. Aquaculture 128:203-209

Munshi SK, Rahman MM, Noor R (2012) Detection of virulence potential of diarrheagenic Escherichia coli isolated from surface water rivers surrounding Dhaka city. J Bangladesh Acad Sci 36:109-122

Nakamura Y, Takano T, Yasuike M, Sakai T, Matsuyama T, Sano M (2013) Comparative genomics reveals that a fish pathogenic bacterium Edwardsiella tarda has acquired the locus of enterocyte effacement (LEE) through horizontal gene transfer. BMC Genomics 14:642

Noor R, Acharjee M, Ahmed T, Das KK, Paul L, Munshi SK, Urmi NJ, Rahman F, Alam MJ (2013) Microbiological analysis of major sea fish collected from local markets in Dhaka city, Bangladesh. J Microbiol Biotechnol Food Sci 2:2420-2430

Postollec F, Falentin H, Pavan S, Combrisson J, Sohier D (2011) Recent advances in quantitative PCR (qPCR) applications in food microbiology. Food Microbiol 28:848-861

Rahman F, Noor R (2012) Prevalence of pathogenic bacteria in common salad vegetables of Dhaka Metropolis. Bangladesh J Botany 41:159-162

Rahman MM, Rahman F, Afroze F, Yesmin F, Fatema KK, Das KK, Noor R (2012) Prevalence of pathogenic bacteria in shrimp samples collected from hatchery, local markets and the shrimp processing plant for export quality frozen shrimps. Bangladesh J Microbiol 29:7-10

Rajadurai NP (1985) Improving the quality of shrimp through proper handling. INFOFISH Int 1:50-52

Sawhney A (2005) Quality measures in food trade: the Indian experience. The World Econ 28:329-348

Sultana S, Tarafder GH, Siddiqui TA, Shaha BC, Walliullah M, Ahmed T, Munna MS, Noor AF, Popy SK, Das KK, Acharjee M, Urmi NJ, Rahman T, Noor R (2014) Microbiological quality analysis of shrimps collected from local market around Dhaka city. Int Food Res J 21:33-38

Wallace BJ, Guzewich JJ, Cambridge M, Altekruse S, Morse DL (1999) Seafood associated disease outbreaks in New York, 1980-1994. Am J Prev Med 17:48-54

World Health Organization (2008) Foodborne disease outbreaks: guidelines for investigation and control. WHO Press, Geneva, Switzerland

World Health Organization (2013) Research priorities for the environment, agriculture and infectious diseases of poverty. WHO Press, Geneva, Switzerland

Yogananth N, Bhakyaraj R, Chanthuru A, Anbalagan T, Nila KM (2009) Detection of virulence gene in Aeromonas hydrophila isolated from fish samples using PCR technique. Global J Biotech Biochem 4:51-53

Yuan JB, Zhang XJ, Liu CZ, Wei JK, Li FH, Xiang JH (2013) Horizontally transferred genes in the genome of pacific white shrimp, Litopenaeus vannamei. BMC Evol Biol 13:165

Zhang YL, Ong CT, Leung KY (2000) Molecular analysis of genetic differences between virulent and avirulent strains of Aeromonas hydrophila isolated from diseased fish. Microbiol 146:999-1009

doi:10.1186/2193-1801-3-469

Cite this article as: Noor et al:: Molecular characterization of the virulent microorganisms along with their drug-resistance traits associated with the export quality frozen shrimps in Bangladesh. SpringerPlus 2014 3:469.

\section{Submit your manuscript to a SpringerOpen ${ }^{\odot}$ journal and benefit from:}

- Convenient online submission

- Rigorous peer review

- Immediate publication on acceptance

- Open access: articles freely available online

- High visibility within the field

- Retaining the copyright to your article

Submit your next manuscript at $\gg$ springeropen.com 